\title{
PERAN MAHKAMAH KONSTITUSI DALAM MENJAMIN HAK KONSTITUSIONAL WARGA NEGARA PADA PROSES DEMOKRATISASI DI INDONESIA
}

\author{
Mutiara Hikmah'
}

\begin{abstract}
Abstrak
The Constitutional Court as the judicial authority is responsible for maintaining the constitution directly and participates in strengthening the rights of human rights. This is drawn directly from the nature of the understanding that the constitution itself as a political document that protects the rights of human rights of every citizen and people who live in the country. This began the constitutional functions of the most essential are the first, limiting the powers contained in the constitutional scheme of a nation, and second, to formulate protection constitutional rights of the citizens and the rights of human as a whole. That is why the role of the Constitutional Court directly correlated with the significance of the role of enforcement agencies of human rights in terms of "norms control". Embodiment of constitutional and judicial review is examining through compliance with the norms of the constitution messages that cannot be separated from the universality of normative messages of human rights.
\end{abstract}

Kata kunci: Mahkamah Konstitusi, hak konstitusional, hak asasi, proses demokratisasi.

\section{Pendahuluan}

Salah satu prinsip penting dalam suatu negara demokrasi adalah terdapatnya kemandirian kekuasaan kehakiman. ${ }^{2}$ Kemandirian kekuasaan kehakiman dapat terwujud dengan dukungan yang kondusif dan memadai dari aspek-aspek struktural-institusional, substantif, kultural, kepemimpinan yang baik, kesejahteraan yang memadai dan partisipasi masyarakat.

1 Staf Pengajar untuk kelompok mata kuliah Hukum Perdata Internasional dan Hukum dan HAM di FHUI. Alamat korespondensi: mtiara90@yahoo.com.

${ }^{2}$ Kekuasaan kehakiman yang merdeka dan bertanggung jawab merupakan bagian dari pilar demokrasi yaitu pemerintahan yang terbuka, akuntabel dan responsif. Lihat: Muladi, Demokratisasi, Hak Asasi Manusia Dan Reformasi Hukum di Indonesia, (Jakarta: The Habibie Center, 2002), hal. 228. 
Mengingat betapa pentingnya kemandirian kekuasaan kehakiman dan merupakan suatu hal yang sangat prinsipiil, maka harus ditegaskan dan dijamin dalam konstitusi dan peraturan perundang-undangan lainnya. ${ }^{3}$

Kemerdekaan atas kekuasaan kehakiman merupakan hak asasi manusia, namun simultan dengan kemerdekaan tersebut manusia juga mempertanyakan sampai seberapa jauh kemerdekaan tersebut juga mengandung tanggung jawab kekuasaan kehakiman. Tanggungjawab kekuasaan kehakiman pada dasarnya merupakan suatu konsep yang merefleksikan hubungan tertentu antara subyek dengan nilai-nilai sosial. ${ }^{4}$ Dalam hal ini terkandung dua hal penting, yaitu kekuasaan kehakiman dan akuntabilitas dalam penggunaan kekuasaan kehakiman tersebut.

Usaha untuk menciptakan kekuasaan kehakiman yang merdeka dan bertanggungjawab di Indonesia menjadi semakin besar dalam era reformasi, mengingat reformasi sendiri harus diartikan sebagai usaha rasional dan sistematik dari seluruh bangsa Indonesia untuk mengaktualisasikan nilai-nilai dasar demokrasi. ${ }^{5}$ Aktualisasi nilai-nilai dasar demokrasi tersebut sebenarnya mempunyai dasar sejarah yang sangat kuat, mengingat negara RI lahir melalui perjuangan fisik yang teramat berat menentang penjajahan. Perjuangan itu mengandung pesan moral untuk senantiasa menegakkan dan mempromosikan nilai-nilai HAM. Mempromosikan dan menegakan HAM merupakan salah satu elemen utama supremasi hukum, dan supremasi hukum sendiri merupakan salah satu inti nilai demokrasi.

Sebagai hasil dari agenda reformasi nasional tahun 1998, UndangUndang Dasar Negara Repubilk Indonesia Tahun 1945 telah mengalami perubahan yang dilaksanakan dalam satu rangkaian empat tahap, yaitu pada tahun 1999, 2000, 2001 dan 2002. Dengan perubahan-perubahan itu, pokokpokok pikiran yang terkandung dalam Undang-Undang Dasar mengalami pergeseran dan perubahan mendasar, sehingga mengubah pula corak dan format kelembagaan serta mekanisme hubungan antara lembaga-lembaga negara yang ada di negara ini. ${ }^{6}$

$$
\begin{aligned}
& { }^{3} \text { Ibid. } \\
& { }^{4} \text { Ibid., hal. } 222 \text {. }
\end{aligned}
$$

${ }^{5}$ Jeremy Bentham dalam hal ini berpendapat bahwa masyarakat yang demokratis menyerupai bentuk piramid yang ditopang oleh tiga pilar utama yaitu, sistem pemilihan umum yang jujur dan adil; jaminan terhadap hak-hak dan kebebasan sipil serta politik; dan sistem pemerintahan yang terbuka, akuntabel dan responsif. Lihat: Muladi, Ibid., hal. 224.

${ }^{6}$ Mutiara Hikmah, "Peran Mahkamah Konstitusi Dalam Penegakan Hukum Dan HAM Di Indonesia", dalam Jurnal Hukum \& Pembangunan, tahun ke-35 No.2, April-Juni 2005, hal. 129. 
Dalam Pasal $24 \mathrm{C}$ hasil perubahan Ketiga Undang-Undang Dasar Negara Republik Indonesia Tahun 1945, ide pembentukan Mahkamah Konstitusi diadopsikan ke dalam konstitusi negara kita sebagai organ konstitusional baru yang sederajat kedudukannya dengan Mahkamah Agung. ${ }^{7}$ Lahirnya Mahkamah Konstitusi ditandai dengan diundangkannya Undang-Undang No. 24 Tahun 2003 Tentang Mahkamah Konstitusi. ${ }^{8}$

Dalam konteks ketatanegaraan, Mahkmah Konstitusi dikonstruksikan sebagai pengawal konstitusi yang berfungsi menegakan keadilan konstitusional ditengah kehidupan masyarakat. Mahkamah Konstitusi bertugas mendorong dan menjamin agar konstitusi dihormati dan dilaksanakan oleh semua komponen negara secara konsisten dan bertanggung jawab.

\section{Hak Konstitusional Warga Negara Dan Hak Asasi Manusia}

Hak konstitusional adalah semua hak yang disuratkan dalam undangundang dasar. Hak-hak konstitusional itu mencakup baik hak asasi manusia maupun hak-hak lainnya. ${ }^{9}$ Hak asasi manusia merupakan hak dasar yang secara kodrati melekat pada diri manusia, bersifat universal dan langgeng, oleh karena itu harus dilindungi, dihormati, dipertahankan dan tidak boleh diabaikan, dikurangi atau dirampas oleh siapapun. Dalam pembahasan mengenai hak asasi manusia, ada beberapa teori yang relevan yang bertujuan untuk melindungi hak asasi manusia (untuk selanjutnya disingkat dengan HAM), antara lain:

7 Ide pembentukan Mahkamah Konstitusi merupakan salah satu perkembangan pemikiran hukum dan kenegaraan modern yang muncul pada abad ke-20 ini. Ditinjau dari aspek waktu, negara Indonesia tercatat sebagai negara ke-78 yang membentuk Mahkamah Konstitusi sekaligus merupakan negara pertama di dunia pada abad ke-21 yang membentuk lembaga ini. Pembentukan Mahkamah Konstitusi RI yang berdiri sendiri ini, merupakan langkah yang diambil negara RI, setelah Austria pada tahun 1920, Italia pada tahun 1947 dan Jerman pada tahun 1948. Lihat: Jimly Asshiddiqie, "Struktur Ketatanegaraan Indonesia Setelah Perubahan Keempat UUD 1945", (Makalah pada Seminar Pembangunan Hukum Nasional VIII, Denpasar, 2003).

${ }^{8}$ Di dalam Pasal 1 Undang-Undang Mahkamah Konstitusi, mendefinisikan bahwa: "Mahkamah Konstitusi adalah salah satu pelaku kekuasaan kehakiman sebagaimana dimaksud dalam Undang-Undang Dasar Negara Republik Indonesia Tahun 1945". Kemudian dijelaskan di dalam Pasal 2 Undang-Undang tersebut bahwa: "Mahkamah Konstitusi merupakan salah satu Lembaga Negara yang melakukan kekuasaan kehakiman yang merdeka untuk menyelenggarakan peradilan guna menegakkan hukum dan keadilan."

${ }^{9}$ Ibid. 
Teori Perjanjian Masyarakat dari John Locke $(1632-1704)^{10}$. Menurut John Locke, sebelum terbentuknya negara, manusia yang dianugerahi berbagai hak oleh alam, dapat menggunakan hak-haknya itu dengan bebas sesuai dengan keinginannya. Oleh karena manusia mempunyai akal budi, mereka mengadakan perjanjian masyarakat untuk membentuk masyarakat/negara dan mengangkat penguasa politik. Dalam perjanjian itu disepakati bahwa individu menyerahkan seluruh hak-haknya yang diberikan oleh alam, kecuali hak-hak yang tidak mungkin dipisahkan dari manusia, yaitu hak hidup (life), hak kemerdekaan (liberty), dan hak milik (property). Ketiga hak dasar itulah yang merupakan hak asasi manusia yang harus dijamin oleh undang-undang dasar yang merupakan batas bagi penguasa untuk tidak melanggarnya. ${ }^{11}$

Teori Trias Politika dari Montesquieu (1688-1755). ${ }^{12}$ Dalam teorinya, Montesquieu mengemukakan, bahwa kekuasaan negara itu terdiri dari tiga cabang kekuasaan, yaitu cabang kekuasaan legislatif, cabang kekuasaan eksekutif, dan cabang kekuasaan yudikatif. Agar hak asasi manusia terlindung dari kesewenang-wenangan penguasa, ketiga cabang kekuasaan itu baik fungsi maupun organ yang melaksanakannya harus dipisahkan (separation of power), tidak boleh bertumpu pada satu tangan. Ketiga kekuasaa yang memiliki kedudukan yang setara itu harus saling mengimbangi satu dengan lainnya (checks and balances system). Jika dihubungkan dengan kondisi di Indonesia, maka lembaga (organ) yang dibentuk dalam rangka pemajuan hak asasi manusia antara lain: ${ }^{13}$

a. Pengadilan Hak Asasi Manusia, yang dibentuk berdasarkan Undang-Undang No. 26 Tahun 2000 tentang Pengadilan Hak Asasi Manusia: ${ }^{14}$

10 John Locke seorang berkebangsaan Inggris, adalah pemikir pertama yang memberikan dasar teori tentang hak asasi manusia (hak kodrati). Lihat: H.A. Roestandi, SH., Ibid., hal. 63 .

${ }^{11}$ Ibid., hal. 64.

${ }^{12}$ Ibid., hal. 65 .

${ }^{13}$ Ibid., hal. 102.

${ }^{14}$ Pengadilan Hak Asasi Manusia bertugas dan berwenang memeriksa dan memutus:

1) Pelanggaran HAM yang berat, termasuk yang dilakukan oleh Warga Negara Indonesia di luar batas wilayah Negara RI;

2) Pelanggaran HAM yang berat meliputi kejahatan genosida dan kejahatan terhadap kemanusiaan; 
b. Komisi Hak Asasi Manusia (Komnas HAM) dibentuk berdasarkan Undang-Undang No. 39 Tahun 1999 tentang Hak Asasi Manusia. ${ }^{15}$

Teori Kedaulatan Rakyat dari Jean Jacques Rousseau. Menurut Rousseau, kekuasaan tertinggi (keadaulatan) ada pada rakyat. Penguasa diangkat oleh rakyat untuk melindungi hak asasi manusia. Apabila penguasa tidak berhasil melaksanakan tugasnya, maka kehendak rakyat dapat menjatuhkannya, dan rakyat akan mengangkat penguasa baru.

Teori Negara Hukum Murni dari Immanuel Kant (1724-1804). Menurut Kant, tujuan negara adalah untuk melindungi segenap warganya. Untuk mencapai tujuan itu Negara harus nerperan sebagai penjagmalam, yang tidak boleh turut campur dalam urusan social, ekonomi dan budaya masyarakat. Negara hanya bertugas menjaga ketertiban dalam masyarakat. Untuk itu perlu dibentuk hukum yang berdasarkan HAM, pemisahan kekuasaan, pemerintahan berdasarkan hukum, dan pengadilan tata usaha negara untuk menyelesaikan pelanggaran hak asasi manusia yang dilakukan oleh penguasa.

Menurut Julius Stahl, konsep Negara Hukum (rechtsstaat) itu mencakup empat elemen penting, yaitu: ${ }^{16}$

1. Perlindungan hak asasi manusia;

2. Pembagian kekuasaan;

3. Pemerintahan berdasarkan undang-undang;

4. Peradilan tata usaha negara.

Teori Rule of Law dari Dicey (1835-1922). Menurut Dicey, untuk melindungi HAM, perlunya penegakan rule of law (pemerintahan oleh hukum, bukan oleh manusia) yang harus memenuhi tiga unsur, yaitu supremasi hukum, kesederajatan di depan hukum, dan penyelesaian perkara

3) Untuk memeriksa pelanggaran HAM yang berat yang dilakukan sebelum Undang-undang Pengadilan HAM berlaku, dengan persetujuan DPR, Presiden membentuk Pengadilan HAM Ad Hoc.

${ }^{15}$ Komnas HAM bertujuan mengembangkan kondisi yang kondusif bagi pelaksanaan HAM sesuai dengan Pancasila, Piagam PBB serta Deklarasi Universal HAM, dan meningkatkan perlindungan dan penegakan HAM guna pengembangan pribadi manusia Indonesia seutuhnya dan kemampuan berpartisipasi dalam berbagai bidang kehidupan. Untuk mencapai tujuannya, Komnas HAM melaksanakan fungsi pengkajian, penelitian, penyuluhan, pemantauan, dan mediasi tentang HAM.

${ }^{16}$ Jimly Asshiddiqie, "Konstitusi \& Konstitusionalisme Indonesia", Edisi Revisi, (Jakarta: Penerbit Sekretariat Jenderal dan Kepaniteraan Mahkamah Konstitusi RI, 2006), hal. 152. 
menurut hukum,tidak sewenang-wenang. Teori rule of law dari Dicey tersebut, telah menjadi bagian yang tak terpisahkan dalam pembahasan mengenai sistem pemerintahan negara di Indonesia.

Dalam sistem pemerintahan negara, di dalam konstitusi ditegaskan bahwa negara Indonesia adalah Negara Hukum (Rechtsstaat), bukan Negara Kekuasaan (Machtstaat). Di dalamnya terkandung pengertian adanya pengakuan terhadap prinsip supremasi hukum dan konstitusi, dianutnya prinsip pemisahan dan pembatasan kekuasaan menurut sistem konstitusional yang diatur dalam Undang-Undang Dasar, adanya jaminan-jaminan hak asasi manusia dalam Undang-Undang Dasar, adanya prinsip peradilan yang bebas dan tidak memihak yang menjamin persamaan setiap warga negara dalam hukum, serta menjamin keadilan bagi setiap orang termasuk terhadap penyalahgunaan wewenang oleh pihak yang berkuasa.

\section{Peran Mahkamah Konstitusi Dalam Menjamin Hak Konstitusional Warga Negara}

Konstitusi (dalam bahasa Inggris "Constitution") berarti undangundang dasar, dalam arti keseluruhan peraturan-peraturan, baik tertulis maupun tidak, mengatur secara mengikat cara-cara bagaimana suatu pemerintahan diselenggarakan dalam suatu masyarakat. Dalam sistem pemerintahan Negara Republik Indonesia, Undang-undang Dasar Negara RI Tahun 1945 adalah hukum dasar yang tertulis. ${ }^{17}$ Menurut Herman Heller Konstitusi memiliki tiga pengertian, yaitu. ${ }^{18}$

1. Konstitusi mencerminkan kehidupan politik di dalam masyarakat sebagai suatu kenyataan dan belum merupaka Konstitusi dalam arti hukum; ${ }^{19}$

2. Setelah orang mencari unsur-unsur hukumnyadari Konstitusi yang hidup dalam masyarakat itu untuk dijadikan sebagai suatu kesatuan kaidah hukum, maka Konstitusi itu disebut Rechtverfassung (Hukum Konstitusi);

${ }^{17}$ Dalam Bahasa Indonesia, konstitusi berarti hukum dasar. Lihat: Muladi (editor), "Hak Asasi Manusia, Hakekat, Konsep dan Implikasinya Dalam Perspektif Hukum Dan Masyarakat", (Bandung: Refika Aditama, 2005), hal. 40.

${ }^{18} \mathrm{Ibid}$., hal. 41.

${ }^{19}$ Dengan perkataan lain, Konstitusi itu masih merupakan pengertian sosiologis atau politis dan belum merupakan pengertian hukum. 
3. Kemudian orang-orang menulisnya dalam suatu naskah sebagai undang-undang yang tertinggi yang berlaku dalam suatu Negara.

Setiap Undang-undang Dasar, memuat ketentuan-ketentuan mengenai hal-hal sebagai berikut: ${ }^{20}$

1. Organisasi Negara;

2. Hak-hak asasi manusia;

3. Prosedur mengubah undang-undang dasar;

4. Ada kalanya memuat larangan untuk mengubah sifat tertentu dari undang-undang dasar. ${ }^{21}$

Semua hak yang disuratkan dalam undang-undang dasar disebut hak konstitusional. Hak-hak konstitusional itu mencakup baik hak asasi manusia, maupun hak-hak lainnya. Contoh dalam UUD Negara RI Tahun 1945, hak konstitusional tercantum di bawah Bab XA tentang Hak Asasi Manusia (Pasal 28A sampai dengan $28 \mathrm{~J}$ ) serta dalam pasal-pasal lain, yang bukan di bawah Bab XA, antara lain Pasal 27, 28, 29 dan Pasal 31.

Hak-hak konstitusional warga Negara yang terdapat dalam UUD Negara RI Tahun 1945 yang termasuk ke dalam Hak Asasi Manusia adalah:

1. Hak untuk hidup serta hak untuk mempertahankan hidup dan kehidupannya (Pasal 28A);

2. Hak untuk membentuk keluarga dan melanjutkan keturunan melalui perkawinan yang sah (Pasal 28B ayat 1 );

3. Hak bagi anak atas kelangsungan hidup, tumbuh, dan berkembang, serta hak atas perlindungan dari kekerasan dan diskriminasi (Pasal 28B ayat 2);

4. Hak untuk mengembangkan diri melalui pemenuhan kebutuhan dasarnya, hak untuk mendapat pendidikan dan memperoleh manfaat dariilmu pengetahuan dan teknologi, seni dan budaya, demi meningkatkan kualitas hidupnya dan demi kesejahteraan umat manusia (Pasal $28 \mathrm{C}$ ayat 1 );

5. Hak untuk memajukan dirinya dalam memperjuangkan haknya secara kolektif untuk membangun masyarakat, bangsa dan negaranya (PAsal 28C ayat 2);

\section{${ }^{20}$ Ibid.}

${ }^{21}$ Hal ini biasanya terdapat jika para penyusun undang-undang dasar ingin menghindari terulangnya kembali hal-hal yang baru saja dialami, seperti misalnya muncul seorang diktator. 
6. Hak atas pengakuan, jaminan, perlindungan, dan kepastian hukum yang adil serta perlakuan yang sama di hadapan hukum (Pasal $28 \mathrm{D}$ ayat 1 );

7. Hak untuk bekerja serta mendapat imbalan dan perlakuan yang adil dan layak dalam hubungan kerja (Pasal 28D ayat 2);

8. Hak untuk memperoleh kesempatan yang sama dalam pemerintahan (Pasal 28D ayat 3);

9. Hak atas status kewarganegaraan (Pasal 28D ayat 4);

10. Serta hak-hak lain yang tercantum di Dalam Pasal 28E sampai dengan Pasal $28 \mathrm{~J}$.

Hak konstitusional lainnya yang terdapat di dalam Undang-Undang Dasar 1945 antara lain:

1. Hak warga negara di bidang hukum dan pemerintahan (Pasal 27 ayat 1$)$;

2. Hak warga negara dalam memperoleh pekerjaan dan penghidupan yang layak bagi kemanusiaan (Pasal 27 ayat 2);

3. Hak warga negara untuk turut serta dalam pembelaan negara (Pasal 27 ayat 3);

4. Hak warga negara untuk berserikat dan berkumpul, mengeluarkan pikiran dengan lisan dan tulisan (Pasal 28);

5. Hak warga negara untuk memeluk agama masing-masing dan untuk beribadat menurut agama dan kepercayaannya itu (Pasal 29 ayat 2);

6. Hak warga negara untuk mendapat pendidikan (Pasal 31 ayat 1).

Dari uraian hak-hak konstitusional tersebut, jika dihubungkan dengan peran atau fungsi Mahkamah Konstitusi, maka Mahkamah Konstitusi mempunyai peran sebagai pengawal konstitusi, agar dilaksanakan dan dihormati baik oleh penyelenggara kekuasaan negara maupun oleh warga negara.

Mahkamah Konstitusi merupakan salah satu lembaga negara yang bertugas melakukan kekuasaan kehakiman yang merdeka untuk menyelenggarakan peradilan guna menegakkan hukum dan keadilan. ${ }^{22}$ Mahkamah Konstitusi memiliki visi "Tegaknya konstitusi dalam rangka mewujudkan cita-cita negara hukum dan demokrasi demi kehidupan kebangsaan dan kenegaraan yang bermartabat".

${ }^{22}$ Indonesia. Undang-Undang No. 24 Tahun 2003 Tentang Mahkamah Konstitusi, Pasal 2. 
Misi dari Mahkamah Konstitusi adalah: $:^{23}$

1. Mewujudkan Mahkamah Konstitusi sebagai salah satu pelaku kekuasaan kehakiman yang modern dan terpercaya.

2. Membangun konstitusionalitas Indonesia dan budaya sadar berkonstitusi.

Dengan adanya Mahkamah Konstitusi, proses penjaminan demokrasi yang konstitusional diharapkan dapat diwujudkan melalui proses penjabaran dari empat kewenangan konstitusional dan satu kewajiban Mahkamah Konstitusi serta penyelesaian persengketaan yang bersifat konstitusional dan dapat diselesaikan secara demokratis. ${ }^{24}$

Dalam Undang-undang Mahkamah Konstitusi Pasal 10, diuraikan mengenai wewenang Mahkamah Konstitusi, antara lain:

1. Mahkamah Konstitusi berwenang mengadili pada tingkat pertama dan terakhir yang putusannya bersifat final untuk :

a. menguji undang-undang terhadap Undang-Undang Dasar Negara Republik Indonesia Tahun 1945;

b. memutus sengketa kewenangan lembaga negara yang kewenangannya diberikan oleh Undang-Undang Dasar Negara Republik Indonesia Tahun 1945;

c. memutus pembubaran partai politik; dan

d. memutus perselisihan tentang hasil pemilihan umum.

2. Mahkamah Konstitusi wajib memberikan putusan atas pendapat DPR bahwa Presiden dan/atau Wakil Presiden diduga telah melakukan pelanggaran hukum berupa pengkhianatan terhadap negara, korupsi, penyuapan, tindak pidana berat lainnya, atau perbuatan tercela, dan/atau tidak lagi memenuhi syarat sebagai Presiden dan/atau Wakil Presiden sebagaimana dimaksud dalam UUD Negara RI Tahun 1945.

Mahkamah Konstitusi berfungsi sebagai pengawal dan penjaga agar konstitusi ditaati dan dilaksanakan secara konsisten, serta mendorong dan mengarahkan proses demokratisasi berdasarkan konstitusi. Selain itu, Mahkamah Konstitusi berperan sebagai penafsir tunggal dan tertinggi atas

${ }^{23}$ Mahkamah Konstitusi Republik Indonesia. "Booklet tentang Sejarah Pembentukan, Visi dan Misi Mahkamah Konstitusi RI”, (Jakarta: Penerbit Mahkamah Konstitusi RI, 2006), hal. 4. 
Undang-Undang Dasar, yang direfleksikan melalui putusan-putusan sesuai dengan kewenangannya. ${ }^{25}$

Kehadiran Mahkamah Konstitusi di Indonesia berperan sebagai pengawal konstitusi, agar konstitusi selalu dijadikan landasan dan dijalankan secara konsisten oleh setiap komponen negara dan masyarakat. Hal tersebut merupakan bagian yang penting dalam proses demokratisasi di Indonesia.

\section{Proses Demokratisasi di Indonesia}

Demokrasi dapat digambarkan sebagai suatu piramida yang mengandung empat bagian, yang masing-masing bagian terdiri dari berbagai indikator kinerja yang dapat diperiksa untuk mengukur seberapa jauh suatu negara benar-benar demokratis. Keempat bagian piramida tersebut jika diuraikan secara singkat adalah: ${ }^{26}$

1. Sistem pemilihan yang bebas dan adil (free and fair elections). Dalam hal ini, terdapat beberapa indikator antara lain:

(a) Pemilihan umum yang berbasis pada kompetisi terbuka,

(b) Hak pilih dan sistem pemilihan yang bersifat rahasia,

(c) Pemberian kesempatan yang sama untuk menduduki jabatanjabatan publik tanpa diskriminasi,

(d) Adanya pemerintahan yang independen dan bebas dari penyalahgunaan kekuasaan serta pengaruh-pengaruh eksternal terhadap pemilih,

(e) Adanya akses yang adil dan sama partai politik dan calon untuk menggunakan media dan sarana-sarana komunikasi yang lain.

2. Pemerintahan yang terbuka, bertanggung jawab dan responsif. Ada beberapa indikator antara lain:

(a) Keterbukaan informasi terhadap apa yang dilakukan penguasa;

(b) Efek dari kebijakan;

(c) Independensi dari sarana-sarana informasi milik pemerintah;

(d) Efektivitas pengawasan terhadap pejabat pemerintah baik sipil maupun militer;

(e) Efektivitas pengawasan parlemen terhadap eksekutif;

${ }^{25}$ Cetak Biru Mahkamah Konstitusi, Op.Cit., hal. 46.

${ }^{26}$ Muladi, Op.Cit., hal. 21. 
(f) Ketaatan eksekutif terhadap "the rule of law";

(g) Transparansi pengaturan yang mengendalikan kekuasaan eksekutif;

(h) Jaminan pengadilan bahwa eksekutif taat pada hukum termasuk efektivitas acaranya;

(i) Adanya kekuasaan kehakiman yang merdeka dari pengaruh eksekutif dan pengaruh serta bentuk-bentuk campur tangan yang lain;

(j) Adanya administrasi hukum yang terbuka bagi efektivitas pengawasan publik;

3. Perlindungan terhadap hak-hak asasi manusia, khususnya hak-hak sipil dan politik. Hal ini mencakup:

(a) Seberapa jauh hukum mendefinisikan hak-hak sipil dan politik serta kebebasan warga Negara, dan seberapa jauh pula hal ini terlindungi;

(b) Kebebasan dari diskriminasi dalam menikmati hak-hak tersebut;

(c) Seberapa jauh keberadaan lembaga-lembaga sukarela dikembangkan dalam rangka pemantauan terhadap pelaksanaan hak-hak tersebut;

(d) Seberapa jauh efektivitas prosedur dan sistem sosialisasi hak-hak tersebut terhadap masyarakat;

(e) Seberapa jauh perlindungan terhadap pengungsi dan imigran yang membuthkan perlindungan.

4. Rasa percaya diri warga Negara dalam kehidupan demokratis atas dasar kekuatannya sendiri untuk mempengaruhi pelbagai keputusan kolektif yang bermanfaat bagi kehidupannya. Beberapa hal yang penting untuk diperhatikan adalah:

(a) Ketiadaan diskriminasi terhadap minoritas atas dasar kesepakatan nasional;

(b) Pengawasan terhadap lembaga-lembaga non pemerintah di bidang HAM;

(c) Pluralisme media komunikasi;

(d) Partisipasi masyarakat dalam kehidupan ekonomi, sosial, budaya, politik atas dasar prinsip keterbukaan. 
Dalam hubungannya dengan reformasi hukum ${ }^{27}$ dalam kerangka empat dasar demokrasi di atas, pemerintah seyogyanya secara sistematis menerapkan reformasi yang didasarkan pada elemen-elemen konsep sistem hukum yaitu: ${ }^{28}$

1. Struktur hukum (semacam suatu lembaga, mesin lintas sektoral dari sistem hukum);

2. Substansi hukum (produk dari mesin, yaitu hukum, aturan-aturan yang actual, norma dan pola perilaku orang-orang dalam suatu sistem);

3. Budaya hukum (perilaku orang terhadap hukum dan sistem hukum, iklim dari pemikiran social dan kekuatan social yang menetukan bagaimana hukum digunakan, dihindari atau disạlahgunakan).

Dengan mempertimbangkan konsep sistem hukum di atas, pemerintah dan pembentuk undang-undang memusatkan perhatian reformasi hukum terhadap lima kepentingan hukum berikut ini, antara lain: ${ }^{29}$

1. Peraturan perundang-undangan di bidang sosial politik harus sedapat mungkin mengakomodasi prinsip-prinsip demokrasi, contohnya undang-undang pemiihan umum yang adil (UndangUndang No. 10 Tahun 2008 tentang Pemilu);

2. Peraturan perundang-undangan yang berkaitan dengan upaya pemulihan ekonomi, yang menekankan pada persiapan untuk menghadapi kecenderungan pasar internasional yang tak

${ }^{27}$ Reformasi hukum di Indonesia harus dipandang sebagai bagian integral dari proses demokratisasi yang tidak boleh berhenti selama pemerintahan terselenggara.

${ }^{28}$ Muladi, Op. Cit., hal. 29. Pembahasan mengenai sistem hukum, merupakan konsep yang berasal dari hasil kajian salah satu ahli bernama Lawrence M.Friedman, yang menyatakan bahwa setiap sistem hukum selalu mengandung tiga unsur, yaitu structure/struktur, substance/substansi dan legal culture/budaya hukum. Yang dimaksud dengan substansi adalah aturan, norma, dan pola prilaku nyata manusia yang berada pada sistem itu. Penekanannya disini terletak pada hukum yang hidup (living law), bukan hanya pada aturan kitab hukum (law books). Yang dimaksud dengan struktur adalah kerangka/ rangkanya, bagian yang tetap bertahan, bagian yang memberi semacam bentuk dan batasan terhadap keseluruhan sistem hukum. Sistem hukum terus berubah, namun bagian-bagian sistem hukum itu berubah tidak secepat bagian tertentu lainnya. Sedangkan yang dimaksud dengan budaya hukum adalah sikap manusia terhadap hukum dan sistem hukumkepercayaan, nilai, pemikiran serta harapannya. Lihat: Lawrence M. Friedman, "The Legal System: A Social Science Perspective", (New York: Rasel Sage Foundation, 1975), hal. 15.

${ }^{29}$ Muladi, Ibid. 
terhindarkan, seperti Undang-undang tentang Bank Sentral yang memberikan kewenangan kepada Bank Indonesia untuk menjalankan kebijakan moneter secara independen, undangundang perlindungan konsumen, undang-undang anti monopoli, undang-undang kepailitan, undang-undang arbitrase dan alternatif penyelesaian sengketa, dan inisiatif untuk membangun programprogram ekonomi yang bekerjasama dengan berbagai organisasi internasional;

3. Peraturan perundang-undangan tentang pemajuan dan perlindungan HAM, seperti Undang-undang HAM, Undangundang Pengadilan HAM untuk mengadili pelanggaran berat HAM, ratifikasi berbagai instrumen HAM serta berbagai konvensi organisasi perburuhan internasional;

4. Peraturan perundang-undangan tentang pemerintahan yang bersih, akuntabel dan responsif. Dalam hal ini termasuk di dalamnya pembaharuan undang-undang pemberantasan korupsi, undangundang tentang penyelenggara negara yang bersih dan bebas dari $\mathrm{KKN}^{30}$ juga termasuk di dalamnya undang-undang pembentukan Mahkamah konstitusi;

5. Peraturan perundang-undangan untuk melindungi dan memperkuat masyarakat yang demokratis sebagai masyarakat yang memiliki rasa percaya diri. Dalam hal ini, termasuk undangundang yang memajukan dan melindungi kebebasan pers, pluralisme media komunikasi dan kebebasan berekspresi.

Dari penjabaran lima kepentingan hukum di atas, dapat dikatakan bahwa dengan lahirnya Mahkamah Konstitusi, proses penjaminan demokrasi yang konstitusional diharapkan dapat diwujudkan melalui kewenangan konstitusional dan kewajiban Mahkamah Konstitusi serta penyelesaian persengketaan yang bersifat konstitusional dan dapat diselesaikan secara demokratis. $^{31}$

Jika mengacu pada Pasal 24 ayat (2) UUD Negara RI Tahun 1945, Mahkamah Konstitusi adalah salah satu lembaga negara dan sebagai salah satu pelaku kekuasaan kehakiman, disamping Mahkamah Agung. Jika dilihat dari perspektif Trias Politika, Mahkamah Konstitusi merupakan salah satu pelaku dalam cabang kekuasaan yudikatif. Keberadaan Mahkamah Konstitusi adalah untuk menguji suatu undang-undang terhadap Undang-

${ }^{30}$ Antara lain mencakup kewajiban penyelenggara negara untuk mengumumkan harta kekayaan dan aset-asetnya.

${ }^{31}$ Cetak Biru MKRI, Op. Cit., hal. 46. 
Undang Dasar 1945, serta kewenangan lainnya, yaitu memutus sengketa kewenangan lembaga negara, perselisihan hasil pemilu, pembubaran partai politik, dan memutus pendapat DPR mengenai dugaan pelanggaran hukum Presiden dan/atau Wakil Presiden. ${ }^{32}$

Dalam Undang-undang No. 24 Tahun 2003 tentang Mahkamah Konstitusi, mengenai tugas dan kewenangan Mahkamah Konstitusi telah diatur secara ekplisit di dalam Pasal 2 dan Pasal 10. Sehubungan dengan wewenang Mahkamah Konstitusi yang terdapat di dalam Pasal 10 ayat 1 butir (d), yaitu memutus perselisihan tentang hasil pemilihan umum. Dalam memasuki usianya yang genap enam tahun, untuk kedua kalinya dalam sejarah pemilu di Indonesia, perselisihan hasil Pemilu diadili dan diputus oleh Mahkamah Konstitusi.

Sengketa hasil Pemilu pada tahun 2004, yang diajukan parpol sebanyak 23 pemohon dengan total perkara 252. Parpol yang paling banyak dikabulkan permohonannya adalah PAN dan PKS. ${ }^{33}$ Mahkamah Konstitusi telah memutus seluruh perkara dengan putusan yang bersifat final. ${ }^{34}$ Sedangkan sengketa hasil Pemilu tahun 2009, sampai saat ini terdapat beberapa perkara yang telah diputus oleh Mahkamah Konstitusi, sehubungan dengan adanya peerselisihan hasil Pemilu Tahun 2009. Sampai dengan 2 Agustus 2009, statistik perkara yang terdapat pada Mahkamah Konstitusi RI adalah sebagai berikut: ${ }^{35}$

a. Perkara pengujian Undang-Undang, sebanyak 90 perkara (sejak tahun 2003);

b. PerkaraSengketa Kewenangan Antar Lembaga Negara, sebanyak 10 perkara (sejak tahun 2003);

c. Perkara Perselisihan Hasil Pemilu Daerah Tahun 2009, sebanyak 26 perkara;

32 Dalam Pasal 10 ayat (2) Undang-Undang Mahkamah Konstitusi, diuraikan mengenai pelanggaran hukum Presiden/Wakil Presiden, berupa: penghianatan terhadap negara, korupsi, penyuapan, tindak pidana berat lainnya, atau perbuatan tercela, dan/atau tidak lagi memenuhi syarat sebagai presiden dan/atau Wakil Presiden.

${ }^{33}$ Berita Mahkamah Konstitusi, Edisi Khusus 2004, hal. 4.

${ }^{34}$ Putusan yang bersifat final, artinya putusan-putusan dari Mahkamah Konstitusi bersifat pertama dan terakhir, sehingga tidak dapat dilakukan upaya hukum lagi mengenai putusan tersebut.

${ }^{35}$ Sumber: <http://www.mahkamahkonstitusi.go.id/>, diakses pada 2 Agustus 2009. 
d. Perkara Perselisihan Hasil Pemilu Tahun 2009, sebanyak 722 perkara (termasuk perkara parpol dan DPD).

\section{Penutup}

Dalam proses demokratisasi di Indonesia, peran Mahkamah Konstitusi merupakan salah satu pelaku dalam cabang kekuasaan yudikatif. Keberadaan Mahkamah Konstitusi adalah untuk menguji suatu undangundang terhadap Undang-Undang Dasar 1945, serta kewenangan lainnya, yaitu memutus sengketa kewenangan lembaga negara, perselisihan hasil pemilu, pembubaran partai politik, dan memutus pendapat DPR mengenai dugaan pelanggaran hukum Presiden dan/atau Wakil Presiden. Dengan adanya Mahkamah Konstitusi, proses penjaminan demokrasi yang konstitusional diharapkan dapat diwujudkan melalui proses penjabaran dari empat kewenangan konstitusional dan satu kewajiban Mahkamah Konstitusi serta penyelesaian persengketaan yang bersifat konstitusional dan dapat diselesaikan secara demokratis. Dalam hubungannya dengan memutus sengketa hasil Pemilu, Mahkamah Konstitusi telah berperan sebagai pemutus sengketa hasil Pemilu yang dilakukan sebanyak dua kali, yaitu Pemilu Tahun 2004 dan Pemilu tahun 2009.

Dalam menjamin hak konstitusional warga negara, Mahkamah Konstitusi mempunyai peran sebagai pengawal konstitusi, agar dilaksanakan dan dihormati baik oleh penyelenggara kekuasaan negara maupun oleh warga negara. Mahkamah Konstitusi juga menjadi penafsir akhir konstitusi dan juga menjadi pelindung konstitusi yang juga berarti memberikan penguatan terhadap hak asasi manusia yang merupakan bagian dari hak konstitusional warga negara. 


\section{Daftar Pustaka}

\section{A. Buku}

Alrasyid, Harun. Naskah UUD 1945 Sesudah Empat kali dirubah oleh MPR. Jakarta: UI Press, 2004.

Asshiddiqie, Jimly. Konstitusi \& Konstitusionalisme Indonesia. Jakarta: Setjen dan Kepaniteraan Mahkamah Konstitusi RI, 2006.

. Reformasi Dan Reposisi Lembaga-lembaga Tinggi Negara. Jakarta, 2000.

. dan Mustafa Fakhri. Mahkamah Konstitusi: Kompilasi Ketentuan Konstitusi, Undang-Undang Dan Peraturan di 78 Negara. Jakarta: Pusat Studi HTN dan Asosiasi pengajar HTN \& HAN Indonesia, 2002.

- Model-Model Pengujian Konstitusional Di Berbagai Negara. Jakarta: Sekretariat Jenderal Dan Kepaniteraan Mahkamah Konstitusi RI, 2006.

Baehr, Peter et.al (Penyunting). Instrumen Internasional Pokok Hak- hak Asasi Manusia. Jakarta: Yayasan Obor Indonesia, 2001.

Bahar, Saafroedin. Konteks Kenegaraan Hak Asasi Manusia. Jakarta: Pustaka Sinar Harapan, 2002.

Black's Law Dictionary. Sixth edition. St. Paul Minnesota, West Publishing \& Co. 1990.

Cipto Handoyo, B.Hestu. Hukum Tata Negara, Kewarganegaraan dan Hak Asasi Manusia (Memahami Proses Konsolidasi Sistem Demokrasi Di Indonesia). Cetakan I. Yogyakarta: Universitas Atmajaya, 2002.

Departemen Kehakiman dan HAM RI. Instrumen Pokok Hak Asasi Manusia Internasional Bagi Aparat Penegak Hukum, Jakarta: kerjasama UNHCR, Departemen Kehakiman dan HAM \& POLRI, 2002.

Fakultas Hukum UI, Informasi Peraturan Perundang-undangan RI, bulan Januari - Oktober tahun XXVI, 2003, Buletin bulanan yang diterbitkan Pusat Dokumentasi Hukum FHUI.

. Informasi Peraturan Perundang-undangan RI, bulan Januari 2004 - bulan Desember 2004. 
. Informasi Peraturan Perundang-undangan RI, bulan Januari 2005 - bulan Desember 2005.

Huijbers, Theo. Filsafat Hukum. Cetakan ke IX. Jakarta: Penerbit Kanisius, 2003.

Koentjaraningrat. Metode-metode Penelitian Masyarakat. Cetakan ke VIII. Jakarta: PT. Gramedia, 1986.

Kusuma, M. Indriadi dan Wahyu Effendy. Kewarganegaraan Indonesia. Catatan Kritis atas HAM dan Institusionalisasi Diskriminasi Warga Negara. Jakarta: Penerbit FKKB \& GANDI, 2002.

Mahkamah Konstitusi RI. Cetak Biru Membangun Mahkamah Konstitusi Sebagai Institusi Peradilan Yang Modern dan Terpercaya. Jakarta: Mahkamah Konstitusi RI, 2004.

Marzuki, Laica. Berjalan-jalan di Ranah Hukum. Jakarta: Sekretariat Jenderal Dan Kepaniteraan Mahkamah Konstitusi RI, 2006.

Muladi. Demokratisasi, Hak Asasi Manusia dan Reformasi Hukum di Indonesia. Jakarta: The Habibie Center, 2002.

. (Editor). Hak Asasi Manusia. Hakekat, Konsep dan Implikasinya dalam Perspektif Hukum dan Masyarakat. Cetakan I. Bandung: Refika Aditama, 2005.

Nowak, Manfred. Introduction to The International Human Rights Regime. Leiden/Boston: Martinus Nijhoff Publishers, 2003.

Roestandi, Achmad. Mahkamah Konstitusi Dalam Tanya Jawab. Jakarta: Sekretariat Jenderal Dan Kepaniteraan Mahkamah Konstitusi RI, 2006.

Siahaan, Maruarar. Hukum Acara MAhkamah Konstitusi Republik Indonesia. Edisi revisi. Jakarta: Sekretariat Jenderal Dan Kepaniteraan Mahkamah Konstitusi RI, 2006.

Soedarsono. Mahkamah Konstitusi Sebagai Pengawal Konstitusi. Jakarta: Sekretariat Jenderal Dan Kepaniteraan Mahkamah Konstitusi RI, 2006.

\section{B. Artikel, Pidato dan Laporan Penelitian}

Bari Azed, Abdul. "Reformasi Politik Hukum Kewarganegaraan Sebagai Agenda Pembaharuan Hukum", Pidato Pengukuhan sebagai Guru 
Besar Tetap Hukum Tata Negara Fakultas Hukum UI. Depok, 15 Oktober 2003.

Hikmah, Mutiara. "Peran Mahkamah Konstitusi Dalam Penegakan Hukum Dan HAM Di Indonesia”, dalam Jurnal Hukum \& Pembangunan, tahun ke-35 No.2, April-Juni 2005.

Nurtjahjo, Hendra, Sophian Martabaya dan Mutiara Hikmah. Laporan Penelitian, "Konstitusionalitas Komisi Kebenaran dan Rekonsiliasi", Kerjasama Pusat Studi Hukum Tata Negara FHUI dengan Mahkamah Konstitusi RI, Depok 2005.

\section{Peraturan Perundang-Undangan}

Indonesia. Naskah UUD Negara RI Tahun 1945 setelah amandemen keempat.

. Undang-Undang No. 39 Tahun 1999 tentang Hak Asasi Manusia.

. Undang-Undang No. 26 tahun 2000 tentang Pengadilan HAM.

. Undang-undang No. 24 Tahun 2004 tentang Mahkamah Konstitusi.

. Keputusan Presiden RI No. 147/M Tahun 2003 tentang Pengangkatan Hakim Mahkamah Konstitusi.

. Keputusan Presiden RI No. 40 Tahun 2004 tentang Rencana Aksi Nasional Hak Asasi Manusia Tahun 2004 - 2009.

. Keputusan Presiden RI No. 51 Tahun 2004 tentang Sekretariat Jenderal dan Kepaniteraan Mahkamah Konstitusi RI.

Mahkamah Konstitusi. Peraturan Mahkamah Konstitusi No. 2/PMK/2003 tentang Kode Etik dan Pedoman Tingkah Laku Hakim Konstitusi. 